\title{
Hypoglycemia and Acute Stroke Presented with Athetosis: A Clinical Appearance
}

\author{
Atetozla Prezente Olan Hipoglisemi ve Akut İnme: Klinik Görünüm
}

Keywords: Acute stroke, athetosis, globus pallidus, hypoglycemia

Anahtar Kelimeler: Akut inme, atetoz, globus pallidus, hipoglisemi

\section{Dear editor,}

A 64-year-old, right-handed male patient who was admitted to the emergency outpatient clinic due to the new onset involuntary movements on his left arm and leg had a history of diabetes mellitus for 11 years with occasional hyperglycemic and hypoglycemic attacks. There was no feature found in his medical history except having hypothyroidism and diabetes mellitus. In addition, his family history was unremarkable.

During his neurological examination, he was conscious, cooperative, and oriented. Cranial nerve examinations were within the normal limits, and there was no lateralized motor loss found. Plantar responses were bilateral flexor. He had a severe left hemiathetosis in a flowing, curving, and twisting manner, which resulted in severe disability. Athetotic movements were more prominent in the upper extremity than in the lower extremity. They disappeared during the sleep and increased in a state of stress.

In the laboratory examination, his initial blood glucose was $61 \mathrm{mg} / \mathrm{dl}$ (<70 mg/dl hypoglycemia), $\mathrm{HbA}_{1} \mathrm{C}:$ 9.3, magnesium: $1.3 \mathrm{mEg} / \mathrm{l}$, calcium: $8.4 \mathrm{mEg} / \mathrm{l}$, and hemoglobin: $9.8 \mathrm{~g} / \mathrm{dl}$. Thyroid function tests were within the normal limits. An electrocardiography showed normal sinus rhythm. No pathology was observed in the computerized brain tomography. In brain diffusion magnetic resonance imaging (MRI), diffusion restriction was detected in the right globus pallidus externa (Figure 1), and its stroke-compatible equivalent was observed in the apparent diffusion coefficient weighted imaging (Figure 2). In contrast-

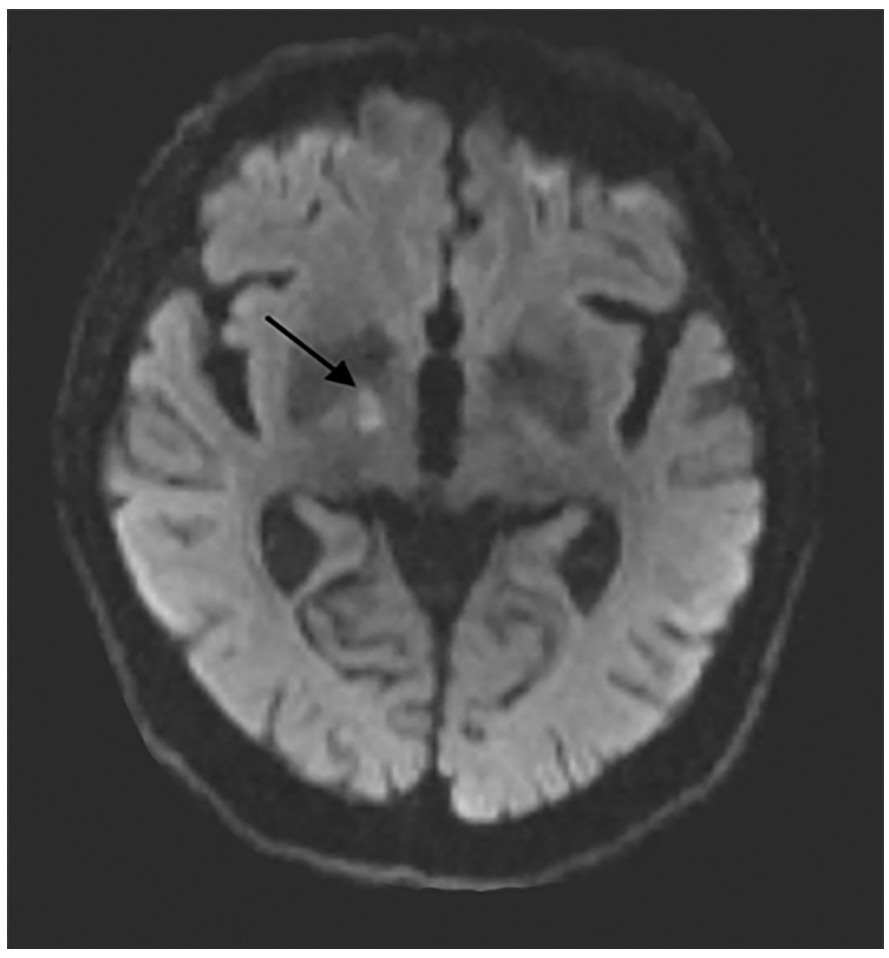

Figure 1. Acute diffusion restriction in the right globus pallidus externus (arrow)

Address for Correspondence/Yazıssma Adresi: Fatma Yilmaz Can MD, University of Health Sciences Turkey, Diskapi Yildirim Beyazit Training and Research Hospital, Clinic of Neurology, Ankara, Turkey 


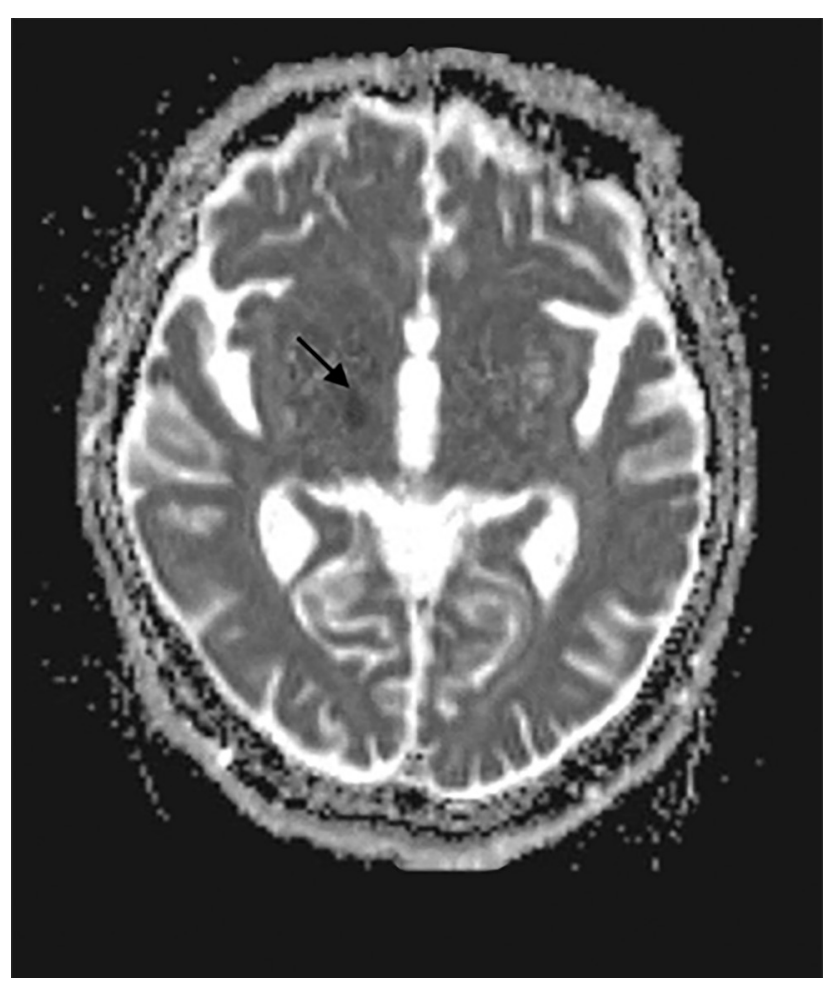

Figure 2. Diffusion coefficient corresponding (arrow)

enhanced MRI, no additional pathology was observed except for diffusion restriction in the right globus pallidus externa. Transthoracic echocardiography was found to be normal. There were fibroatheroma plaques that did not cause significant stenosis, found in the carotid Doppler ultrasonography. The patient was treated for blood glucose regulation. Oral acetylsalicylic acid 300 $\mathrm{mg} /$ day and subcutaneous enoxaparin sodium $8000 \mathrm{IU} /$ day were started due to the ischemic stroke. The blood glucose was $61 \mathrm{mg} /$ $\mathrm{dl}$ at the beginning; it increased to $68 \mathrm{mg} / \mathrm{dl}$ and $176 \mathrm{mg} / \mathrm{dl}$ in the follow-ups at three-hour intervals. Despite the regulation of blood glucose levels, the patient's movement disorder did not improve. Therefore, it was thought that the patient's movement disorder developed due to an acute stroke.

Haloperidol treatment was started for hemiathetosis. It was continued by increasing the dose, and the patient partially benefited from haloperidol on the fifth day of the treatment. The patient was discharged on the fifth day of the treatment by his own will.

Our patient was in the risk group for cerebral ischemia because he was over 50 years old and diabetic (1). He had a lesion consistent with an acute ischemia in the right globus pallidus externus, and he had hemiathetosis on the contralateral side (1). The lesion was in the form of lacunar infarction (2). Movement disorder occurred in the acute period. Since the lesion of our patient was localized to the globus pallidus externus, it was thought that it caused athetosis with an excitatory effect (1) by interrupting the inhibitory indirect pathway between the cerebral cortex and the basal ganglia.

\section{Ethics}

Informed Consent: Patient consent was obtained.

Peer-review: Externally peer-reviewed.

\section{Authorship Contributions}

Concept: M.F.Ö., Design: F.Y.C., M.F.Ö., Data Collection or Processing: F.Y.C., B.N.Ç., Analysis or Interpretation: F.Y.C., M.F.Ö., Literature Search: F.Y.C., B.N.Ç., Writing: F.Y.C., B.N.Ç.,

Conflict of Interest: No conflict of interest was declared by the authors.

Financial Disclosure: The authors declared that this study received no financial support.

\section{References}

1. Nakawah MO, Lai EC. Post-stroke dyskinesia. Neuropsychiatr Dis Treat 2016;12:2885-2893.

2. McCollum D, Silvers S, Dawson SB, Barrett KM. Resolution of acute onset hemichorea-hemiballismus after treatment with intravenous tissue plasminogen activator. Neurohospitalist 2013;3:131-134. 